\title{
MENCARI MODEL TATA IBADAH DALAM GEREJA KRISTEN NAZARENE DI INDONESIA DI ABAD XXI ${ }^{1}$
}

\author{
Oleh: Bakhoh Jatmiko
}

\begin{abstract}
Worship is one expression of a human as a spiritual being. Deep inside a person, there is always a spiritual awareness that makes the person have a need of spiritual relationship with the Creator. In the Church context, worship is conducted with many forms and elements. The number of denominations and liturgies often lead to both a confusion and longing for a formulation or guidance in shaping a liturgy. The style and concept of worship in the Nazarene Church in Indonesia needs an emphasise on its understanding related to the denomination's history. The Nazarene Church has been in existence Indonesia for almost four decades and spread to many different places in Indonesia.
\end{abstract}

Keywords : worship, nazarene, church, liturgy.

\begin{abstract}
Abstrak
Ibadah adalah salah satu bentuk aktualisasi diri manusia sebagai makluk spiritual. Di dalam diri manusia terdapat kesadaran spiritual yang membuat manusia memiliki kebutuhan untuk membangun hubungan dengan Sang Pencipta. Dalam Gereja, ibadah dilakukan dengan berbagai macam bentuk dan unsur di dalam pelaksanaannya. Banyaknya denominasi dan liturgi menimbulkan kebingungan sekaligus kerinduan untuk membuat rumusan maupun panduan yang dapat digunakan sebagai acuan dalam menyusun tata ibadah. Format dan konsep ibadah dalam Gereja Kristen Nazarene di Indonesia juga memerlukan rumusan dan penegasan berhubungan dengan pemahaman maupun bentuk ibadah yang harus digunakan di gereja-gereja lokal mengingat sejarah denominasi yang ini sudah ada di Indonesia hampir empat dekade dan sudah tersebar di berbagai tempat di Indonesia.
\end{abstract}

Kata Kunci : ibadah, nazarene, gereja, liturgi.

\section{Pendahuluan}

1 Diseminarkan dalam pertemuan Pendeta dan Hamba-hamba Tuhan GKN Jawa-Bali, Jakarta, 18 September 2018.

${ }^{2}$ Penulis adalah Dosen di Sekolah Tinggi Theologia Nazarene Indonesia. 
Artikel ini ditulis sebagai respon terhadap banyaknya pertanyaan seputar model liturgi yang seharusnya dipakai di dalam ibadah di Gereja Kristen Nazarene. Dalam konteks GKN Global, sejak di dirikan pada bulan Oktober 1895 di Los Angeles oleh Dr. Phineas F. Bresee dan orang-orang yang berkomitmen pada gerakan Kekudusan Wesley; GKN telah melewati satu abad sejarah dalam perubahan dan perkembangan nama denominasi, peraturan, organisasi termasuk juga dalam liturgi. Sidang gabungan Persekutuan Pentakosta Amerika, Gereja Kristen Nazarene dan Gereja Kristen Kekudusan Kristus pada tahun 1908 ditambah dengan gerakan misi abad XIX membuat GKN menjadi denominasi dengan dimensi internasional. Pada waktu itu, GKN dibawa hingga Afrika (Cape Verde dan Afrika Selata), Asia (India dan Jepang), dan Amerika Selatan (Meksiko). GKN Terus berkembang dan didirikan hingga Amerika Tengah, Karibia, Australia, Negara-negara di Pasifik Selatan dan negara-negara yang lain. ${ }^{3}$ Hingga pada tahun 2016 (abad XXI) ini, GKN telah ada di 162 negara di dunia dan memiliki 2,5 juta jiwa anggota penuh. Di sisi lain, dalam konteks tata ibadah, GKN juga ditantang untuk mengakomodir corak global-nya, tanpa harus meninggalkan teologi pokoknya.

Dalam konteks perkembangan GKN di Indonesia, pengaruh berkembangnya denominasi di negara ini juga membuat hamba-hamba Tuhan yang melayani di GKN melakukan kajian, perbandingan hingga adaptasi dari "denominasi" tetangga yang diyakini mampu menjawab kebutuhan umat dalam bidang penyembahan. Abad XXI yang diwarnai dengan gelombang globalisasi teknologi dan komunikasi juga memberi sumbangsih bagi setiap gereja lokal untuk ikut "berselancar" melihat model dan cara beribadah dari gereja-gereja lain baik di dalam maupun luar negeri. Kemudian banyaknya variasi dalam liturgi yang dijumpai dalam gerejagereja lokal GKN juga menjadi isu yang menggiring kepada pertanyaan: Haruskah liturgi GKN

\footnotetext{
${ }^{3}$ Gereja Kristen Nazarene, "Pernyataan Historis" dalam Buku Pedoman tahun 2013-2017, (Kansas City, Missouri: Nazarene Publishing House), 2013, hal. 16-27.
} 
diseragamkan? Atau liturgi "yang ini" atau "yang itu” kah yang merupakan liturgi asli atau liturgi adaptasi maupun modifikasi? Faktor lain lagi yang menjadikan pembahasan dan kajian dalam topik ini diperlukan adalah adanya hamba-hamba Tuhan yang memiliki pengalaman melayani di denominasi lain, atau mendapatkan pendidikan di lembaga pendidikan teologi non Nazarene; yang kemudian memutuskan untuk melayani di GKN.

Penulis akan berusaha melakukan kajian dan pembahasan dengan menggunakan sumber dan pendekatan biblikal, dokumen resmi denominasi ${ }^{4}$, kajian dari para penulis yang sudah terlebih dahulu melakukan riset tentang liturgi maupun ibadah serta pengalaman penulis dalam mengikuti berbagai ibadah di GKN di indonesia, GKN di berbagai negara di regional AsiaPasifik, maupun GKN di regional-regional lain.

\section{Berbagai Definisi}

Ibadah

Kata "Ibadah" memiliki pengertian yang luas dan sangat ditentukan oleh konteks dimana kata ini dipakai. Secara umum, menurut Kamus Besar Bahasa Indonesia, kata "Ibadah" diartikan sebagai perbuatan untuk menyatakan bakti kepada Allah, yang didasari ketaatan mengerjakan perintah-Nya dan menjauhi larangan-Nya. ${ }^{5}$ Definisi tersebut menjelaskan bahwa ibadah adalah sebauh tindakan sebagai bentuk bakti tetapi juga diserta dengan aksi yang berupa ketaatan kepada Tuhan.

\footnotetext{
${ }^{4}$ Buku Pedoman Gereja Kristen Nazaren, Jati Diri Nazarene, Misional (Diterjemahkan ke dalam bahasa Indonesia Kristen, Kudus, Misioner), Website GKN nazarene.org.

${ }^{5}$ http://www.kamusbesar.com, diakses 1 Agustus 2018.
} 
Di dalam bahasa Indonesia, kata "ibadah" memiliki sinonim dengan kata "bakti" yang menurut Kamus Besar Bahasa Indonesia dapat diartikan sebagai tunduk dan hormat; perbuatan yg menyatakan setia (kasih, hormat, tunduk), memperhambakan diri; setia. ${ }^{6}$ Kata bakti menunjukkan sebuah sikap menghargai pihak superior dan juga ekspresi yang merupakan konsekuensi dari sikap yang sebelumnya dimiliki. Sehingga pengertian "Ibadah" dan “Kebaktian" tidak perlu dipertentangkan makna maupun arti di dalam penggunaannya.

Sementara itu, menurut Abineno, ibadah adalah : Pertemuan antara Allah dengan jemaat, dimana dalam pertemuan tersebut berlangsung semacam dialog; Allah berbicara, jemaat menjawab; Allah memberi dan jemaat mengucap syukur; Allah mengampuni, dan Jemaat memuji nama-Nya. ${ }^{7}$

Di dalam definisinya, Abineno menekankan makna hubungan di dalam sebuah ibadah. Definisi serupa juga diberikan oleh Brownlee yang mendefinisikan ibadah sebagai persekutuan dan pertemuan manusia dengan Allah melalui penyerahan diri manusia kepada Allah untuk menjadi saksi Allah dalam dunia sehingga manusia perlu beribadah dengan benar. ${ }^{8}$ Baik Abineno maupun Brownlee memberikan penekanan bahwa ibadah merupakan hubungan dua arah antara Allah dan Jemaat. Definisi ini menggabarkan peran baik Allah maupun umat di dalam setiap ibadah yang diselenggarakan.

Berdasarkan etimologinya, kata "Ibadah" berasal dari kata dalam bahasa Ibrani dalam Perjanjian Lama עִָָָּד - 'avodah atau 'abodah (kata ini serumpun dengan bahasa Arab yang kemudian diserap dalam bahasa Indonesia 'ibadah'). Penggunaan kata avodah di dalam teks

\footnotetext{
${ }^{6}$ Ibid.

${ }^{7}$ Simion Diparuma Harianja, Prestaria Naiboho, Liturgi dan Musik Gerejawi, peny. Maringan Sinambela, Hanna Dewi Aritonang, dan Melinda Siahaan, (Medan: Mitra Dwi Lestari), 2011, hal. 25.

${ }^{8}$ Malcolm Brownlee, Tugas Manusia Dalam Dunia Milik Tuhan: Dasar Theologis Bagi Pekerjaan Orang Kristen Dalam Masyarakat, (Jakarta: BPK. Gunung Mulia), 2004, hal. 19.
} 
Perjanjian Lama tidak hanya digunakan dalam pengertian "Ibadah, pelayanan, worship," tetapi juga digunakan untuk hal yang kemudian diterjemahkan dengan "Pekerjaan."

Kata nomina avodah (Pekerjaan) kemudian memiliki bentuk verbia (Kata Kerja) עָבָ 'avad yang artinya bekerja. Kata ini pertama kali digunakan di dalam Kejadian 2:15, ketika Tuhan menempatkan manusia di Taman Eden untuk mengolah dan mengusahakan ciptaan Tuhan. Kebenaran ini memiliki pengertian implikasi moralitas dalam kata Ibadah bahwa berkerja juga merupakan sebuah pelaksanaan ibadah kepada Allah.

Ibadah juga dipahami sebagai cara manusia untuk datang kepada Tuhan Sang Penciptanya. Hal ini diuangkapkan dalam Septuaginta yang menggunakan kata Leitourgia dalam arti yang terbatas untuk menerjemahkan kata Ibrani "abodah" dalam bahasa Ibrani yang berarti sebuah ritus perayaan yang didalamnya berisi perjumpaan antara Allah dengan umatNya. ${ }^{9}$

Sedangkan di dalam Perjanjian Baru, kata $\lambda \alpha \tau \rho \varepsilon ı \alpha$ - latreia dalam bahasa Yunani digunakan untuk menyatakan 'pengabdian', dan ketika dipakai dalam konteks ritus ibadah, kata latreia berarti "ibadah" (penyembahan). Sebagai contoh di dalam Roma 12:1 terdapat frasa "itu adalah ibadahmu yang sejati." Di dalam teks aslinya, frase ini adalah logike latreia, yang sesuai dengan konteksnya dapat diterjemahkan sebagai penyembahan; pengabdian yang sejati. Ibadah adalah bentuk menyembah, mengabdi kepada Tuhan sebagai tanda hormat dan bakti umat kepada Tuhan.

\section{Liturgi}

${ }^{9}$ Ester Sutanto, Liturgi Meja Tuhan: Dinamika Perayaan-Pelayanan, (Jakarta: Unit Publikasi dan Informasi STT), 2005, hal. 1. 
Istilah "Liturgi" memiliki perngertian yang berkembang dari zaman ke zaman. Konteks kesejarahan dan waktu penggunaan istilah liturgi sangat menentukan pengertian dari kata "Liturgi" itu sendiri. Kata "liturgi" berasal dari bahasa Yunani leiturgia, dan dalam bentuk kata kerja leiturgeo yang artinya melayani, melaksanakan dinas atau tugas, memegang jabatan. ${ }^{10}$ Seperti yang disinggung di atas, kata ini memiliki arti yang lebih luas daripada dalam lingkup gereja saja. Secara harafiah, kata ini berasal dari dua kata leitos yang berarti rakyat, umat dan kata ergon yang berarti perbuatan, pekerjaan, tugas; sehingga leiturgia dapat dimengerti sebagai melakukan pekerjaan untuk rakyat. ${ }^{11}$

Istilah liturgi dalam konteks Yunani kuno berkaitan dengan tugas raja, pejabat, pemerintah, kepada desa yang berkarya bagi umat, kota atau negara. Tindakan ini menunjuk kerja bakti atau kerja pelayanan yang tidak dibayar, iuran atau sumbangan dari masyarakat yang kaya, dan pajak untuk masyarakat atau negara yang diberikan secara sukarela. ${ }^{12}$ Jadi pada awalnya kata ini lebih menunjukkan arti profan pilitis daripada kultis.

Kemudian istilah ini dipakai dalam Septuaginta untuk menunjukkan tugas-tugas yang dikerjakan berkaitan dengan ritus keagamaan. Dalam konteks Perjanjian Baru, kata ini merujuk pada pekerjaan rasul, iman, malaikat dan Kristus sendiri dalam hubungannya dengan keyakinan atau keagamaan. ${ }^{13}$ Istilah ini memiliki pengertian yang terus berkembang di sepanjang sejarah gereja mulai dari masa gereja purba, era reformasi hingga gereja modern. Kata Liturgi kemudian lebih dimengerti sebagai pelayanan ibadah (kultus) kepada dewa-dewa/Tuhan yang biasanya melibatkan persembahan korban dan hymnus (nyanyian pujian kepada dewa atau Tuhan).

\footnotetext{
${ }^{10}$ Ibid, hal. 9.

${ }^{11}$ Ibid, hal. 9-10.

12 James F. White, Pengantar Ibadah Kristen, (Jakarta: BPK Gunung Mulia), 2005, hal. 13-14.

${ }^{13}$ G. Reimer, Cermin Injil, (Jakarta: Yayasan Komunikasi Bina Kasih), 1995, hal. 9-18.
} 


\title{
Ibadah menurut Denominasi GKN
}

\author{
Nilai Inti
}

Gereje Kristen Nazarene memegang teguh tiga nilai (core values) inti yang dijadikan sebagai keyakinan dasar dan panduan dalam pelayanannya. Nilai-nilai inti inilah yang membedakan GKN dengan organisasi yang lain. Tanpa nilai-nilai ini maka, organisasi ini bukan lagi GKN seperti yang lebih dari satu abad yang lalu didirikan oleh Dr. Phineas Breese. Nilainilai inti itu adalah: Kristen, Kudus, Misioner. ${ }^{14}$

Kristen. Kami bersatu dengan seluruh orang percaya untuk menyatakan bahwa Yesus Kristus adalah Tuhan. Kami percaya bahwa dengan kasih-Nya, Allah mengaruniakan kepada seluruh manusia pengampuanan dosa dan pemulihan hubungan. Dalam pendamaian dengan Allah, kami percaya bahwa kami juga didamaikan dengan sesama, mengasihi mereka seperti Allah telah mengasihi kami. Kami percaya bahwa dalam hidup bersama, kami harus memiliki citra karakter Kristus. Bersama dengan umat percaya di semua tempat, kami memegang teguh pengakuan Allah Tritunggal dan percaya kepada iman Kristen serta menjunjung tradisi kekudusan - Wesleyan. Kami berpedoman pada Alkitab sebagai sumber kebenaran rohani yang utama, didukung dengan akal budi, tradisi kekudusan dan pengalaman.

Kudus. Melalui Firman-Nya, kami dipanggil dan ditarik oleh kasih karunia untuk menyembah Allah dan mengasihi Dia dengan segenap hati, jiwa, pikiran, dan kekuatan, dan mengasihi sesama seperti diri sendiri. Untuk hal inilah, kami mengabdikan diri sepenuhnya

\footnotetext{
${ }^{14}$ Disarikan dari Church of the Nazarene, Missional, pen. Panitia Literatur Nazarene Indonesia, (Kansas
} City: International Church of the Nazarene), 2002. 
kepada Allah, percaya bahwa kami bisa "dikuduskan secara menyeluruh" melalui pengalaman krisis kedua. Kami percaya bahwa Roh Kudus menyadarkan, menyucikan, memenuhi dan memberi kuasa kepada kami sebagaimana anugerah Allah memperbaharui kami hari demi hari menjadi pribadi yang memiliki kasih dan disiplin rohani, etis dan penuh kemurnian, serta penuh kasih dan keadilan. Ini adalah karya Roh Kudus yang memulihkan kami kepada gambar Allah dan menghasilkan di dalam diri kami, karakter Kristus. Kekudusan dalam kehidupan orang percaya lebih dikenal sebagai keserupaan dengan Kristus.

Misioner. Kami adalah umat utusan yang menanggapi panggilan Kristus dan memperoleh kuasa dari Roh Kudus untuk pergi ke seluruh dunia, menyaksikan Ketuhanan Kristus dan bersama-sama dengan Allah membangun umat Tuhan dan memperluas kerajaanNya (Mat. 28:19-20; 2 Kor. 6:1). Misi kita (a) dimulai dengan ibadah, (b) melayani dunia dengan memberitakan Injil dan pelayanan kasih, (c) mendorong orang Kristen ke arah kedewasaan melalui pemuridan, dan (d) mempersiapkan pria dan wanita untuk pelayanan Kristen melalui Perguruan Tinggi Kristen.

Gereja Kristen Nazarene menempatkan ibadah sebagai salah satu bagian dalam nilai-nilai inti yang dimilikinya, yaitu : Misioner. Mengingat bahwa nilai inti merupakan jiwa dari sebuah organisasi; maka nilai-nilai inti ini merupakan hal yang tidak boleh hilang, dikurangi maupun dirubah. Jika sebagian nilai inti ini hilang, maka organisasi ini bukan lagi GKN.

Ibadah adalah salah satu bentuk implementasi dari nilai inti Misioner. Ibadah diletakkan bersama-sama dengan pemberitaan Injil dan pelayanan kasih, pemuridan dan pendidikan bagi pelayanan (Lihat gb. 1). Misi GKN dimulai dengan ibadah. Ibadah merupakan bentuk misi yang harus dilakukan sebelum ketiga hal yang lain. Pernyataan ini memberi pengertian bahwa 
sebelum pergi keluar memberitakan Injil, melayani sesama dengan pelayanan belas kasihan dan kemudian memperlengkapi setiap orang yang mendapatkan panggilan khusus; ibadah harus dijadikan tempat implementasi mula-mula.

Tempat dan kedudukan ibadah di dalam GKN sangat jelas. Ibadah disetiap GKN memiliki dimensi misi, dimana panggilan Kristus dinyatakan, Ketuhanan Kristus disaksikan, umat Tuhan di bangun dan kerajaan-Nya diperluas. Pemahaman ini seharusnya mendatangkan kesadaran bahwa ibadah bukan sekedar rutinitas maupun sebuah bentuk praktek kesalehan, bagi umat Nazarene, ibadah adalah sebuah mandat yang harus membawa umat mendengar panggilan dari Tuhan, memproklamasikan Yesus Kristus sebagai Tuhan, membangun dan menguatkan iman jemaat serta mengajar umat melakukan kehendak Tuhan. Kebenaran ini membawa penulis untuk secara berani mengatakan bahwa para penyelenggara ibadah adalah para misionaris yang membawa misi besar di dalam ibadah.

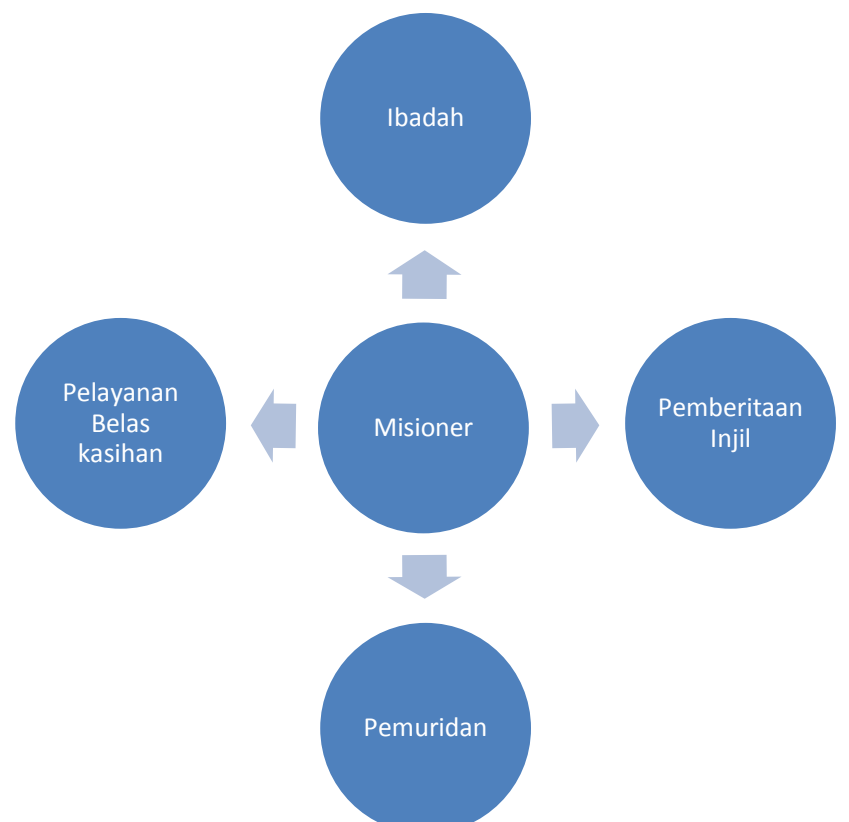


Gambar 1

Elemen Nilai Inti MISIONER

Seperti disebutkan sebelumnya, nilai inti adalah keyakinan dasar yang dimiliki oleh sebuah organisasi. Ketika ibadah menjadi elemen pembangun salah satu nilai inti di dalam GKN, berarti ibadah merupakan hal yang sangat penting dan tidak bisa dilepaskan dari GKN.

\section{Esensi}

Dr. Phineas Bresee, pendiri dan ketua umum pertama GKN mengatakan: Gereja Tuhan, dalam bentuk yang paling mulia di bumi dan di surga memiliki persekutuan, pengajaran dan kesatuan ibadah, tetapi semua hal tersebut untuk menolong setiap pribadi menjadi serupa dengan Kristus. ${ }^{15}$

Menurut Bresee, ibadah adalah ciri khas gereja. Ibadah membedakan gereja dengan segala institusi yang ada di bumi (maupun di surga). Bersama dengan persekutuan dan pengajaran, ibadah menolong setiap orang percaya untuk menjadi serupa dengan Kristus.

\footnotetext{
${ }^{15}$ Gereja Kristen Nazarene, Jati Diri Nazarene, Siapa Kita - Apa yang Kita Percaya, versi PDF diunduh dari www.nazarene.org, hal. 16-17.
} 
Di dalam pernyataan nilai-nilai inti GKN, ibadah dimaknai sebagai ekspresi kasih tertinggi kepada Allah. ${ }^{16}$ Pernyataan ini memiliki makna yang sangat dalam dalam kehidupan orang percaya yang telah dipanggil menjadi umat-Nya. Morgenthaler dalam Worship Evangelism mengambil contoh Daud sebagai teladan dalam ibadah dan penyembahan dimana Daud menempatkan Ibadah dan pujian kepada Allah sebagai prioritas utama, demikianlah hendaknya gereja menempatkan sebuah ibadah. ${ }^{17}$ Umat Allah dapat mengejawantahkan kasih kepada Allah dengan melakukan berbagai hal: memberi, melayani, berkorban dan lain sebagainya, namun ketika umat Tuhan beribadah, itulah ekspresi kasih yang paling mulia yang dapat diberikan kepada Allah.

Implikasi yang lain dari keyakinan bahwa esensi ibadah adalah kasih kepada Allah ialah perlu adanya ketulusan di dalam setiap ibadah yang diselenggarakan. Abineno dalam penelusurannya terhadap kata latreia dalam Septuaginta menegaskan bahwa ibadah kepada Tuhan haruslah dilakukan dengan segenap hati dan segenap jiwa artinya ibadah tersebut dilakukan dengan rasa "takut", penuh "kasih" dan dengan "ketaatan" terhadap ketetapan Allah. ${ }^{18}$

Pemahaman tentang esensi ibadah yang semacam ini akan membawa setiap hamba Tuhan maupun umat di dalam GKN mengerti mengapa mereka harus beribadah. Berdasarkan pengalaman penulis, ketika berdiskusi tentang ibadah, ditemukan berbagai alasan mengapa orang percaya harus beribadah kepada Tuhan. Ada keyakinan yang mengatakan bahwa umat harus beribadah supaya mendapat perkenanan Tuhan, beribadah supaya diberkati Tuhan, beribadah karena merupakan kewajiban atau beribadah supaya mendapatkan berkat. Tanpa bermaksud

\footnotetext{
${ }^{16}$ Ibid.

${ }^{17}$ Sally Morgenthaler, Worship Evangelism: Inviting Unbelievers into the presence of God, (Grand Rapids, Michigan: Zondervan Publishing House), 1999, hal. 38-39.

${ }^{18}$ J.L. Ch Abineno, Apa Kata Alkitab? (Jakarta: BPK. Gunung Mulia), 1983, hal. 17-24.
} 
menjatuhkan penghakiman, GKN memberikan pernyataan yang lugas dan jelas, bahwa umat beribadah sebagai ekspresi kasihnya kepada Allah.

\section{Fokus}

Fokus dalam sebuah ibadah adalah hal yang sangat penting untuk diperhatikan di dalam sebuah ibadah. Fokus ibadah akan menentukan arah dan nilai sebuah ibadah. Brownlee memberikan pandangannya mengenai tiga kesalahan fokus yang seringkali ada dalam sebuah ibadah.

Pertama, Ibadah sebagai alat untuk memperoleh kuasa ilahi atau perkenaan Allah. Pandangan ini seringkali digunakan untuk menyenangkan Allah atau dewa-dewa melalui doa, mantra dan tindakan simbolis untuk mendapatkan kuasa ilahi atau kepentingan pribadi. Pandangan ini menganggap bahwa Allah lebih tertarik kepada ritual ibadah daripada kehidupan sehari-hari. Kedua, Ibadah sebagai jam yang teduh dan Kudus yang terpisah dari masalah-masalah duniawi Brownlee menolak pandangan bahwa ibadah memisahkan diri manusia dari masalah dunia. Ibadah tidak membuat manusia melarikan diri dari masalah dunia, justru dalam ibadah manusia membawa masalah-masalah tersebut kepada Tuhan dan diperlengkapi untuk menghadapi masalah-masalah tersebut. Ketiga, Ibadah sebagai alat untuk menguatkan orang bagi kehidupan sehari-hari. Brownlee menegaskan bahwa gedung Gereja seringkali diperlakukan seperti pompa bensin. Maksudnya, orang-orang datang ke sana untuk mengisi tangkinya supaya bisa berjalan satu minggu lagi. Menurut Brownlee, tujuan utama ibadah ialah memuliakan Allah dan membangun persekutuan dengan Tuhan. Jika kita mendapatkan kekuatan, maka menurut Brownlee, itu adalah tambahan, tetapi bukan yang utama. ${ }^{19}$

Dari uraian yang diberikan oleh Brownlee, kesalahan fokus ibadah terdapat pada siapa subyek yang lebih banyak mendapatkan "keuntungan" dalam sebuah ibadah. Ketiga alasan Brownlee menitik beratkan fokus ibadah pada keuntungan jemaat yang hadir pada ibadah.

${ }^{19}$ Malcolm Brownlee, Tugas Manusia Dalam Dunia Milik Tuhan: Dasar Theologis Bagi Pekerjaan Orang Kristen Dalam Masyarakat, (Jakarta: BPK. Gunung Mulia), 2004, hal. 19-22. 
Dalam topik yang lain, seringkali ibadah dijadikan sebagai alat untuk menghadirkan orang kedalam sebuah gereja. Angka kehadiran ini kemudian dijadikan sebagai parameter dari pertumbuhan gereja tersebut. Secara jujur dan terbuka, seringkali ibadah dalam sebuah gereja "diboncengi" semangat marketing untuk menarik sebanyak mungkin orang untuk datang dan beribadah. Kemajuan teknologi di bidang pertunjukkan dewasa ini membawa gereja ikut "mengendarai" arus kemajuan jaman ini dengan memakai teknologi terkini di dalam setiap ibadahnya. Khususnya di gereja-gereja perkotaan, multimedia, audio, visual menjadi "daya" yang mampu menarik orang untuk datang kesebuah gereja. Dalam kasus ini, seringkali gereja menggunakan terminologi teologis dan biblika untuk mengemas motif penambahan jumlah kehadiran ini dengan istilah "ibadah sebagai media penjangkauan."

Literatur resmi GKN memberikan panduan tentang fokus yang seharusnya dimiliki di dalam sebuah ibadah:

Ibadah berpusat pada Allah dalam penyembahan, dan menghormati Dia satu-satunya yang ada dalam kasih karunia dan rahmat menebus kita . . . bukan mencari pengalaman yang berpusat pada diri sendiri, melainkan untuk berserah dan mengorbankan diri. Gereja yang beribadah adalah gereja yang melayani Allah dengan kasih dan ketaatan. ${ }^{20}$

Ibadah harus menjadikan Allah sebagai pusat utama didalam pujian dan penyembahan yang dilakukan. Gustafson seperti dikutip oleh Morgenthaler menjelaskan bahwa hanya Allah sendirilah yang menjadi gol dalam ibadah, bahkan lebih dari penginjilan. ${ }^{21}$ Allah harus menjadi pusat dan tujuan utama di dalam sebuah ibadah lebih dari apapun juga. Allah harus menjadi pihak utama yang harus "memetik keuntungan” dari sebuah ibadah.

\footnotetext{
${ }^{20}$ Church of the Nazarene, Missional, hal. 16-17.
}

${ }^{21}$ Morgenthaler, Worship Evangelism, hal. 41. 
Di dalam hal isi, literatur resmi GKN tidak mencatat unsur-unsur ibadah dan cenderung tidak mengatur bentuk-bentuk penerapan unsur-unsur tersebut atau bagaimana unsur-unsur itu diterapkan. Di dalam Jati diri Nazarene disebutkan: Di dalam ibadah ada menyanyi, mendengarkan pembacaan Alkitab, memberi persembahan dan persepuluhan, berdoa, mendengar pemberitaan Firman, membaptis dan mengambil bagian dalam Perjamuan Kudus. ${ }^{22}$

Mencermati pernyataan tersebut di atas, GKN tidak memberikan urut-urutan yang tertentu di dalam unsur-unsur liturgi ibadahnya. Sebagai contoh, penekanan yang berbeda dalam susunan dan urut-urutan Liturgi terlihat jelas jika melihat unsur-unsur Liturgi yang pada umumnya dipakai di Gereja Lutheran dan HKBP. ${ }^{23}$

Unsur-Unsur Liturgi Gereja Lutheran; 1) Nyanyian atau Paduan Suara; 2) Votum atau Invovatio; 3) Introitus; 4) Doa; 5) Hukum Taurat; 6) Janji Pengampunan Dosa; 7) Pembacaan Firman Allah (Epistel); 8) Pengakuan Iman Rasuli; 9) Warta Jemaat; 10) Persembahan; 11) Berkat.

Unsur-Unsur Liturgi Gereja HKBP; 1) Nyanyian Jemaat; 2) Votum - Introitus - Doa; 3) Nyanyian Jemaat; 4) Pembacaan Hukum Tuhan; 5) Nyanyian Jemaat; 6) Doa Pengakuan Dosa; 7) Nyanyian Jemaat; 8) Pembacaan Firman (Epistel); 9) Nyanyian Jemaat; 10) Pengakuan Iman; 11) Warta Jemaat; 12) Nyanyian Jemaat sambil mengumpulkan persembahan; 13) Khotbah (Evangelium); 14) Nyanyian Jemaat Sambil mengumpulkan persembahan; 15) Doa Persembahan; 16) Nyanyian Persembahan; 17) Doa Bapa Kami dan Doksologi; 18) Berkat.

\footnotetext{
${ }^{22}$ Gereja Kristen Nazarene, Jati Diri Nazarene, hal. 16-17.

23 Simion Diparuma Harianja, Prestaria Naiboho, Liturgi dan Musik Gerejawi, peny. Maringan Sinambela, Hanna Dewi Aritonang, dan Melinda Siahaan (Medan: Mitra Dwi Lestari), 2011, hal. 24-25.
} 
GKN memiliki tata ibadah yang lebih dinamis jika dibandingkan dengan beberapa gereja di Indonesia yang merupakan hasil dari misi Eropa yang banyak dipengaruhi oleh Gerakan Liturgia yang terjadi pada waktu itu. ${ }^{24}$ Praktek-praktek liturgis yang detail seperti votum, salam, introitus, gloria kecil, kyrie eleison, mazmur, haleluya tidak dituliskan di dalam sumber resmi GKN.

GKN lebih menekankan untuk memberikan pedoman substansial unsur liturgi dari pada bentuk, urut-urutan dan praktek-praktek detail dalam liturgi. Sebagai contoh, memang GKN tidak menyebut adanya introitus atau gloria kecil, namun GKN meyakini bahwa salah satu hal yang dapat dilakukan di dalam sebuah ibadah adalah menyanyi. Sebagai contoh lain, GKN tidak memberikan pedoman detail dan urutan tertentu bagi doa pengakuan, collecta (doa dengan dan untuk jemaat), epiklese (doa berhubungan dengan waktu mendengar Firman Tuhan) ${ }^{25}$; namun GKN secara jelas menyebut hal yang esensial yang merangkum praktek-praktek terbebut dengan "berdoa."

${ }^{24}$ Pembahasan lebih lengkap tentang sejarah unsur-unsur Liturgi di gereja-gereja di Indonesia dapat dibaca di J.L. Ch. Abineno, Unsur-unsur Liturgia yang Dipakai Gereja-gereja di Indonesia, (Jakarta: BPK Gunung Mulia), 2010.

\footnotetext{
${ }^{25}$ Abineno, Unsur-unsur Liturgia, hal. 44-48.
} 


\section{Faktor-faktor Penting Penentu Liturgi Ibadah Dalam GKN}

\section{GKN Sebagai Gereja Global}

Sejak diorganisasi di tahun 1908, GKN terus berkembang dan banyak pelayananpelayanan baru yang dimulai diberbagai negara di dunia. Data terakhir menyebutkan bahwa GKN telah memiliki lebih dari 2,5 juta anggota penuh yang beribadah di lebih dari 30.000 gereja lokal di 162 negara di dunia. ${ }^{26}$ Faktor lain yang akan memperkuat corak "global" dari GKN adalah semangat misional yang dimiliki denominasi ini. GKN adalah salah satu denominasi yang terus berupaya mengutus hamba-hamba Tuhan yang melayani lintas budaya. Sesuai dengan laman resmi GKN, tecatat terdapat lebih dari 700 hamba Tuhan lintas budaya yang diutus dan melayani di berbagai wilayah di dunia. ${ }^{27}$

Corak internasional (Global) dalam GKN menjadi warna dan terus dipertahankan sejak 1908. Bukan hanya di dalam perkembangannya yang mencapai lebih dari 160 negara di dunia, tetapi corak global GKN juga nampak di dalam sejarah kepemimpinan dan momen-momen penting yang ada di dalam perjalanan organisasi GKN. Sesuai dengan catatan di dalam Jati Diri Nazarene, pada sidang umum tahun 1998, dilaporkan bahwa setengah dari semua anggota Nazarene tinggal di luar Amerika Serikat. Kemudian, tahun 2001, 41 persen delegasi yang hadir tidak menggunakan bahasa Inggris sebagai bahasa utama, atau bahkan tidak bisa berbicara dalam bahasa Inggris sama sekali. ${ }^{28}$ Kemudian, pada tahun 2009, salah satu ketua umum terpilih adalah seorang dari Afrika, Eugenio Duarte dari Cape Verde. Sidang umum empat tahun kemudian (Juni 2013) menambahkan Gustavo Crocker, sebagai ketua umum terpilih yang ke 41 sebagai ketua umum GKN yang merupakan seorang Latin - Amerika (Guatelama).

\footnotetext{
${ }^{26}$ http://nazarene.org/about-nazarenes. Diakses 3 Agustus 2018.

27 Ibid.

${ }^{28}$ Gereja Kristen Nazarene, Jati Diri Nazarene, hal. 11.
} 
Kenyataan bahwa GKN adalah gereja yang aktif dalam usaha-usaha pewartaan kabar baik dan terus berusaha membuka pelayanan-pelayanan baru, membawa keyakinan bahwa GKN akan semakin banyak menjangkau daerah maupun negara-negara baru, membuka wilayahwilayah baru dan mendirikan gereja-gereja lokal yang baru. Hal tersebut akan membuat GKN menjadi gereja yang kaya dengan keberagaman bahasa maupun budaya dari segala macam suku dan bangsa. Setiap minggunya, di seluruh dunia, paling tidak terdapat 212 bahasa (termasuk bahasa suku) yang digunakan di dalam ibadah-ibadah di gereja-gereja GKN lokal di seluruh dunia. $^{29}$

Dalam struktur organisasi, GKN global dibagi kedalam enam regional besar yang mewakili baik benua maupun willayah yang memiliki letak geografis yang berdekatan. Regionalregional tersebut adalah: Afrika, Amerika dan Kanada, Eurasia (Eropa dan Asia Timur), Amerika Tengah, Amerika Selatan, Asia Pasifik (Asia, Australia dan Kepulauan Pasifik). Jika diamati, pengelompokan ini tidak seratus persen mewakili kesamaan dan keseragaman. Sebagai contoh, di Regional Asia-Pasifik, disana terdapat keragaman bahasa yang begitu banyak dan juga kekayaan dalam faktor etnologis, antropologis, sosiologis, ekonomi, politik, iklim, ekonomi dan berbagai faktor lain yang menurut Garry Reimer hal-hal seperti tersebut adalah faktor-faktor yang bersama-sama membentuk sebuah liturgi dalam ibadah. ${ }^{30}$

Dengan kekayaan unsur yang ada di GKN, membuat corak liturgi dan ibadah yang sangat beragam. Liturgi dalam GKN tidak dimaksudkan untuk mewakili bangsa tertentu maupun budaya tertentu. GKN memiliki warna yang nampak sebagai gereja Internasional. Bahkan dalam konteks Indonesia sendiri, bentuk dan tata ibadah di dalam GKN tidak selalu sama antara yang

\footnotetext{
${ }^{29} \mathrm{http}$ ///nazarene.org/about-nazarenes, diakses 10 Agustus 2018.

${ }_{30}$ Pembahasan lebih lanjut baca Garry Riemer, Cermin Injil, (Jakarta: Yayasan Komunikasi Bina Kasih), 1995.
} 
satu dengan yang lain. Diskusi dan pemikiran tentang liturgi dan ibadah di GKN akan sangat ditentukan oleh pemahaman tentang "ke-globalan” GKN sebagai gereja internasional.

\section{Konteks Lokal}

Di satu sisi, GKN adalah gereja global yang memiliki keanekaragaman corak dan bentuk khususnya di dalam liturgi ibadah. Pemikiran serta pertanyaan yang muncul dari kenyataan ini adalah, model ibadah seperti apakah yang seharusnya ada di gereja-gereja lokal GKN? Bentuk yang manakah yang harus diadaptasi oleh gereja, bilamana umat datang dan berkumpul untuk beribadah?

Salah satu literatur resmi yang diterbitkan GKN memberikan pernyataan sebagai berikut: Gereja lokal adalah konteks utama untuk beribadah, dimana umat Allah berkumpul - bukan untuk mencari pengalaman yang berpusat pada diri sendiri atau untuk meninggikan diri, melainkan untuk berserah dan mengorbankan diri. ${ }^{31}$

Kalimat tersebut menjelaskan tentang keberadaan gereja lokal sebagai konteks utama di dalam ibadah. Gereja lokal sebagai "wadah" ibadah adalah penentuk bentuk dan liturgi ibadah. Keberadaan gereja lokal akan memberi warna kepada gereja global.

Bentuk akomodasi terhadap keunikan konteks budaya dari setiap gereja lokal masingmasing sudah dipikirkan oleh pendiri GKN sejak 42 tahun yang lalu. Pada tahun 1976, GKN membentuk Komisi Penyelidikan untuk membuat kajian tentang masa depan denominasi GKN.

\footnotetext{
${ }^{31}$ Gereja Kristen Nazarene, Jati Diri Nazarene, hal. 17.
} 
Pada sidang umum tahun 1980, komisi ini memberikan rekomendasi untuk menyetujui adanya kebijakan pemerintahan yang bersifat internasional, dengan dua poin acuan utama:

Pertama, GKN dan wilayah-wilayah secara serentak dikenal sebagai "persekutuan orangorang percaya yang mendunia yang sesuai dengan konteks budaya mereka masingmasing."

Kedua, mengenai komitmen bersama kepada "Misi Khusus dari Gereja Kristen Nazarene," yakni "untuk menyebarkan kekudusan Alkitabiah . . . sebagai unsur utama di dalam inti komitmen yang tidak boleh diubah, yang menunjukkan identitas Nazarene."32

Rekomendasi dari empat dekade yang lalu ini (poin pertama) memberikan jaminan dan kepastian bagi budaya gereja lokal (konteks budaya), untuk ada dan digunakan dengan acuan bahwa praktek tersebut tidak bertentangan dengan komitmen inti GKN yaitu kekudusan Alkitabiah (poin kedua). Hal ini juga memberikan ruang bagi setiap gereja lokal untuk menggunakan dan mengembangkan budaya lokal di dalam liturgi ibadahnya.

Kenyataan ini didukung dengan fakta bahwa liturgi dalam sebuah gereja sangat ditentukan oleh faktor-faktor yang ada di sekelilingnya. G. Reimer menjelaskan bahwa sebuah pola liturgi tercipta karena berbagai kenyataan, yang bersama-sama dan memberikan pengaruh kepada tata ibadah di suatu tempat tertentu, dalam situasi dan waktu tertentu. ${ }^{33}$ Dengan melihat pernyataan Reimer tersebut, sangat penting untuk menyadari bahwa konteks akan menentukan model dan pola dalam sebuah liturgi. Keyakinan inilah yang juga diperhitungkan oleh GKN. Liturgi di gereja lokal yang satu diijinkan untuk memiliki model dan pola liturgi yang berbeda dengan gereja lokal yang lain. Gereja lokal menjadi konteks utama dalam sebuah ibadah.

\section{Dogma Gereja}

\footnotetext{
${ }^{32}$ Ibid, hal. 10.

${ }^{33}$ G. Reimer, Cermin Injil, (Jakarta: Yayasan Komunikasi Bina Kasih), 1995, hal. 28-37.
} 
Penentuan liturgi sebuah gereja sangat dipengaruhi oleh faktor dogma gereja (denominasi) tersebut. Sebagai perbandingan, keyakinan Gereja Katolik Roma terhadap ajaran transubstansiasi membawa pengaruh signifikan terhadap liturgi ibadah khususnya dalam pelaksanaan ekaristi (misa). Gereja Baptis memiliki penekanan pada ajaran tentang baptisan orang dewasa yang mempengaruhi tata cara pelaksanaan ibadah baptisan. Kemudian, gerejagereja Reformasi yang memiliki salah satu dogma yang tidak pernah dilupakan sola Scriptura, membuat ibadah-ibadah di gereja-gereja aliran Reformasi menempatkan khotbah di pusat pusaran sebuah liturginya.

Di dalam GKN dogma gereja juga menjadi alat pemersatu sekaligus rambu-rambu di dalam sebuah tata ibadah. Jurnal Sidang Umum yang ke -20 Gereja Kristen Nazarene membuat rumusan yang merangkul prinsip "keseragaman teologi internasional." ${ }^{\text {34 }}$ Prinsip ini sangat penting dalam hubungannya dengan satunya dogma gereja bagi GKN di seluruh dunia. Warna dan corak konteks lokal yang terjalin dalam gambar GKN global tetapi tetap dibingkai oleh keseragaman teologi internasional. Kebingungan dalam mengambil keputusan ketika hendak memutuskan sebuah unsur atau praktek liturgi dapat dijembatani denga mengajukan pertanyaan pemandu seperti: Bagaimanakah ajaran GKN mengenai unsur atau praktek liturgi tersebut?

Rumusan ini kembali menegaskan rekomendasi dari Komisi Penyelidikan yang mengusulkan dua rekomendasi, khususnya poin kedua tentang inti komitmen terhadap kekudusan yang tidak boleh diubah, yang akan menunjukkan identitas Nazarene. Kekudusan menjadi norma inti dalam menentukan sebuah praktek termasuk di dalamnya dalam memasukkan sebuah unsur ke dalam sebuah liturgi ibadah. Pertanyaan yang perlu diajukan untuk

\footnotetext{
${ }^{34}$ Jurnal Sidang Umum yang Kedua Puluh, Gereja Kristen Nazarene, (1980), hal. 232. Franklin Cook, The International Dimension (1984), hal. 49 seperti dikutip dalam Jati Diri Nazarene, hal. 12.
} 
menentukan sebuah tata ibadah adalah: Apakah unsur maupun praktek itu bertentangan dengan nilai-nilai kekudusan Allah?

Keseragaman dogma gereja dan nilai kekudusan menjadi acuan untuk menentukan sebuah liturgi ibadah dalam konteks lokal masing-masing. Hal ini memberikan kesadaran bahwa penyusunan maupun asesmen sebuah liturgi harus didahului dengan kajian serta pemahaman teologi tentang dogma yang dipegang oleh GKN. Demikian juga degan pertanyaan-pertanyaan terkait dengan bentuk, unsur maupun praktek liturgis dalam GKN perlu mengacu kepada nilainilai kekudusan dan juga dogma dalam GKN.

\section{Kesimpulan}

Kajian tentang liturgi dan ibadah memerlukan pembahasan yang luas sekaligus menjawab mengingat liturgika adalah bagian dari teologi praktika. Dari berbagai definisi yang pernah diberikan oleh para penulis dan teolog Kristen, pada hakekatnya ibadah adalah sebuah bentuk hubungan manusia dan Allah yang diwujudkan dengan bakti dan pemberian syukur manusia kepada Allah. Di dalam ibadah juga terdapat komunikasi dua arah antara Tuhan yang disembah dan manusia sebagai penyembah.

Dalam konteks Gereja Kristen Nazarene, ibadah dimaknai sebagai hal yang penting karena merupakan bagian dari nilai inti yang merupakan penanda khusus dari denominasi ini. Ibadah adalah ekspresi kasih paling luhur yang manusia dapat sampaikan kepada Allah. Hal yang tidak boleh diabaikan di dalam ibadah adalah bahwa fokus utama di dalam ibadah adalah Allah sendiri dan Ia adalah pribadi yang harus dijadikan pusat ibadah lebih dari segal sesuatu. GKN tidak menentukan corak atau liturgi tertentu (kecuali panduan dalam beberapa pelayanan khusus 
- misalnya pernikahan atau baptisan) namun memberikan rambu-rambu dan prinsip umum berhubungan dengan hal-hal yang menjadi unsur ibadah.

Model tata ibadah dalam GKN tidak dibatasi dengan cara dan urutan tertentu mengingat GKN adalah gereja internasional. Penentuan tata ibadah di dalam gereja lokal sebagai tempat orang percaya bersekutu disesuaikan dengan konteks (budaya) tempat dimana gereja lokal tersebut ada. Namun demikian, yang perlu diingat adalah GKN memiliki acuan yang harus menjadi rujukan khususnya dalam menentukan sebuah liturgi. Nilai-nilai kekudusan dan dogma gereja harus menjadi pegangan dalam menentukan atau menilai sebuah unsur maupun praktek ibadah. 


\section{DAFTAR PUSTAKA}

Abineno, J.L. Ch. Unsur-unsur Liturgia yang Dipakai Gereja-gereja di Indonesia. Jakarta: BPK Gunung Mulia, 2010.

Abineno, J.L. Ch. Apa Kata Alkitab? Jakarta: BPK. Gunung Mulia, 1983.

Brownlee, Malcolm. Tugas Manusia Dalam Dunia Milik Tuhan: Dasar Theologis Bagi Pekerjaan Orang Kristen Dalam Masyarakat. Jakarta: BPK. Gunung Mulia, 2004.

Cook, Franklin. The International Dimension, 1984.

Gereja Kristen Nazarene, Buku Pedoman tahun 2013-2017. Kansas City, Missouri: Nazarene Publishing House, 2013.

Gereja Kristen Nazarene, Jati Diri Nazarene, Siapa Kita - Apa yang Kita Percaya, versi PDF diunduh dari www.nazarene.org.

Gereja Kristen Nazarene, Missional, pen. Panitia Literatur Nazarene Indonesia. Kansas City: International Church of the Nazarene, 2002.

Harianja, Simion Diparuma dan Prestaria Naiboho. Liturgi dan Musik Gerejawi, disunting oleh Maringan Sinambela, Hanna Dewi Aritonang, dan Melinda Siahaan. Medan: Mitra Dwi Lestari, 2011.

Jurnal Sidang Umum yang Kedua Puluh, Gereja Kristen Nazarene, 1980.

Morgenthaler, Sally. Worship Evangelism: Inviting Unbelievers into the presence of God. Grand Rapids, Michigan: Zondervan Publishing House, 1999.

Reimer, G. Cermin Injil. Jakarta: Yayasan Komunikasi Bina Kasih, 1995.

Sutanto, Ester. Liturgi Meja Tuhan: Dinamika Perayaan-Pelayanan. Jakarta: Unit Publikasi dan Informasi STT, 2005.

White, James F. Pengantar Ibadah Kristen. Jakarta: BPK Gunung Mulia, 2005.

Website

http://nazarene.org/about-nazarenes

http://www.kamusbesar.com 
24| Jurnal Teologi SANCTUM DOM IN E 